\title{
The Popularity of Burns' “Auld Lang Syne” and Its Production Explained
}

\author{
JIA Hong-xia, XING Long-long, WANG Jing \\ Beijing Information Science and Technology University, Beijing, China
}

\begin{abstract}
Robert Burns' “Auld Lang Syne”, one of the most famous poems on friendship, has enjoyed great popularity ever since its inclusion in Scots Musical Museum in 1788. This paper identifies why “Auld Lang Syne” has been so popular among readers or audience. The author argues that “Auld Lang Syne” owes its popularity partly to its production. Based on the horizon of expectations, the central notion of Jauss' reception aesthetic, the poem's production is explained by focusing on the poet's intention, the poem's theme, and its language features. We find that (1) Burns’ intention of writing “Auld Lang Syne” is possibly due to his personal liking of making friends and social environment, which motivates him to write for both himself and the Scots of his time; (2) the poem's theme is about friendship, one of the universal emotions always cherished and pursued by all human beings, which is bound to meet the expectations of readers or audience; and (3) the language features in “Auld Lang Syne”, such as theatricality, repeatability, musicality, and simplicity, meet the Scottish artistic taste.
\end{abstract}

Keywords: Burns’s “Auld Lang Syne”, popularity, production, reception aesthetic, horizon of expectations

\section{Introduction}

Robert Burns' “Auld Lang Syne” (1788) is one of the most famous poems on friendship in the English language, which reminds people that old friends should never be forgotten (ZHANG \& WU, 2002, p. 179).

“Auld Lang Syne” was contributed by Burns to the fifth volume of James Johnson’s Scots Musical Museum (1787-1803) and was not entirely Burns's composition, but was taken down by him, he wrote, "from an old man’s singing” (Drabble, 2005, p. 51).

Ever since Burns' “Auld Lang Syne” was included in James Johnson’s Scots Musical Museum in 1788, thanks to its emotive words to a melodious tune, especially its theme of friendship, it has become a most popular classic read, sung, and played by people with different culture backgrounds all over the world.

Popular as it is, Burns' “Auld Lang Syne” has received few reviews from critics, especially reviews of its popularity. And most of its reviews are concerned with its theme and language features and translations. Instances on its theme mainly include GAO Wen’s “Emotions in Robert Burns’ Poem” (2011), CHEN Yan-jun’s

\footnotetext{
* Project funded by Beijing Municipal Commission Education for Undergraduate Scientific Research: “Auld Lang Syne in China” (No.: 71C1410849).

JIA Hong-xia, associate professor, M.A., School of Foreign Studies, Beijing Information Science and Technology University. XING Long-long, B.A., School of Foreign Studies, Beijing Information Science and Technology University. WANG Jing, undergraduate, School of Foreign Studies, Beijing Information Science and Technology University.
} 
“Fusion of Time with Emotion: Comments on Burns’ Auld Lang Syne” (2008), ZHAO Dan and MIAO Jun’s “On the Universal Fraternity in Burns' poems” (2010); instances of major language features reviews are SUN Fang's "On the Artistic Features of Alud Lang Syne” (2009), QIAN Ying and LI Shun-xiang’s “Aesthetic Empathy in Alud Lang Syne, a Scottish Poem” (2011). And the points reviewed in these writings may well be helpful for the discussion of the popularity of "Auld Lang Syne".

The present paper, based on the horizon of expectations, the central notion of Hans Robert Jauss' reception aesthetic (1982), aims to have a explanation of “Auld Lang Syne”’s popularity focusing on its production.

\section{Jauss' Reception Aesthetic}

Reception aesthetic is a reader-centered literary theory introduced in Literary History as a Challenge to Literary Theory (1967) by Hans Robert Jauss. Jauss, "an important German exponent of reception theory, gave a historical dimension to reader- oriented criticism” (Seldem, 2004, p. 53). And his reader-oriented criticism is established on a paradigm, which refers to the scientific framework of concepts, such as horizon of expectations, and the three stages of aesthetic practice (including production, circulation, and acceptance).

\section{Horizon of Expectations: The Central Notion of Jauss' Reception Aesthetic}

As the central notion of Jauss' reception aesthetic, horizon of expectations is defined as the set of cultural, ethical, and literary expectations held by readers in the historical moment of a work's appearance (Jauss, 1982, back cover).

Before the emergence of reception aesthetic, researches and writings were author-centered. In 1970, Jauss argued that, radically and subversively, it should be reader-centered (Jauss, 1982, p. 247). He used the term horizon of expectations to describe the criteria readers use to judge literary texts in any given period (Seldem, 2004, p. 53).

He proposed that aesthetic studies should focus on the readers' acceptance, reaction, aesthetic experience, and the dynamic interaction process among authors, works, and readers, as well as the role of the literary social function. He thought that readers should have the right to determine the meaning and value of the text, also the right of acceptance or rejection of the text. And the criterion for readers to judge literary texts is the horizon of expectations. So the production of literary texts aims to meet the readers' horizon of expectations, otherwise, the produced literary texts will not be accepted by the potential readers.

\section{Literary Production, the First Stage in Aesthetic Practice}

The three stages of aesthetic practice, another paradigm or a scientific framework of concepts in Jauss' reception aesthetic, are devoted to the description of the relationship between literary production and acceptance.

Jauss suggested that aesthetic practice should include the following three stages, production, circulation, and acceptance (Iser, 1974). Literature, in a sense, like a commodity, involves three stages: production (creation), circulation (publishing, distribution, etc.), and consumption (acceptance). The three form a unit of organic process, in which each two consist of one pair, that is, the work and the author, the work and the reader. In the former pair, the writer creates an acceptable object for the readers, at the same time, the acceptance of the readers by reading the works fulfills the writer's intention and purpose of creation. Once the text production is completed, away from the author, the written text is at the stage of circulation, then how to read it is the reader's business, and 
it has nothing to do with the author.

In the process of literary production, works are created with horizon of expectations for literary acceptance, here the horizon of expectations of both the author and readers should be the same, otherwise, literary acceptance cannot be fulfilled. Without acceptance, there would be no more production because the value and purpose of literary creation cannot be achieved. The acceptance of readers, therefore, is not only the stimulator of motivation, but the final stage of the creation.

\section{The Production of Burns’ “Auld Lang Syne”}

Burns' production of "Auld Lang Syne”, in a strict sense, is an activity of recording or rewriting based on an old man's singing. While rewriting, he bears his readers' (or users') needs in mind to meet their horizon of expectations. The factors involved in production of “Auld Lang Syne” are Burns' intention, the poem's theme and its language features. And they will be discussed to see why and how the poem comes to its popularity.

\section{Burns' Intention}

Intention is to signify somethig in a writing. And Burns' intention of writing "Auld Lang Syne” is to signify friendship possibly due to his personal likes and social background.

Burns always dreamed of brotherhood and sisterhood. He had lots of friends and kept frequent correspondence with them. On 17th December, 1788, Burns wrote in a letter to Mrs Dunlop, "Your meeting which you so well describe with your old schoolfellow and friend was truly interesting... There is an old song and tune which has often thrilled through my soul” (Chambers, 1852, p. 300). Burns praised it as an old song.

Burns believed that all the people should be unified and fraternal, which are basic human virtues (CHEN, 2008, p. 80). When hearing this song from an old man, Burns noted it down without hesitation, then he recreated it. His "Auld Lang Syne" is a rewriting, fusing the original with some adaptations to meet his persistent pursuit of friendship and the horizon of expectations of readers of his time.

In the 18th century, Scotland witnessed the vigorous development of democracy and culture and the unprecedentedly revival of folk songs and dramas (YUAN, trans. 1981, p. 5). However, the Presbyterian church of Scotland still controlled large parts of Scotland. The emergence of New Lights (a Christian sect) in which Burns and his many housemates joined hit hard on the stubborn Presbyterians. In 1789, the break-out of the French Revolution woke up Burns, and he called on the people of Scotland to pursue freedom, equality, fraternity, and dignity.

\section{The Poem's Theme}

Theme refers to the ideas that the poet explores and the concerns the poem examines (Kirszner \& Mandell, 2006, p. 774).

As a farmer, Burns was warm, cheerful, imaginative, and willing to make friends, and he wrote some popular poems on friendship, in which he advocated the equality, sincerity, loyalty, and fraternity. "John Anderson, My Jo" and "Auld Lang Syne” are two of the most famous songs on friendship in the English language. The former praises sincere friendship between men and the latter reminds people that old friends should never be forgotten.

His “Auld Lang Syne” is about two young people who are good friends during school years. They gradually become estranged from each other after graduation and make their livings separately. Years later, when they 
meet again, they miss the old good days and their kind Scottish friends.

Burns was not overblown the mournfulness of the lost youth. In the poem, a space-time tunnel has been built: On the one hand, he recollects the past; on the other hand, he has a reunion with his old friends and enjoys the joyous drinking together in the reality.

Simple in language, the theme of the friendship is suggested that old friends should never be forgotten. Every "old days" is not identical in time, but every "old days" is always a piece of sweet memory in our lives (ZHAO \& MIAO, 2010, p. 155).

"Auld Lang Syne" echoes a universal truth that the past is gone forever but the friendship should never be forgotten. And we may drink a toast together for friendship and for the future.

Burns' “Auld Lang Syne”, a classic either in the form of a poem or song, will enjoy everlasting popularity as long as the universal value "friendship" is cherished by people all over the world, and as long as the poem or its song exists.

\section{Language Features of “Auld Lang Syne”}

There are several language features in "Auld Lang Syne”, such as theatricality, repeatability, musicality, and simplicity. The application of these artistic techniques makes the poem so melodious and touching. It is no doubt that the striking language features of the poem are part of the reason for its popularity.

Theatricality. Burns inherited the tradition of realism. Almost every poem has its specific description of the plot, which originates from real life. It is the plot of the poem that makes readers sense the poem's authenticity and simplicity.

"Auld Lang Syne" is structured with a plot. It begins with a rhetorical question "Should auld acquaintance be forgot, and never brought to mind?” It is a question of universal significance involving the reader to think. It not only draws the reader's attention, but also highlights the theme of this poem, producing a dramatic effect (SUN, 2009, pp. 105-106).

Its theatricality is also embodied in its climax: the reunion after a long separation—-two friends pick flowers on the mountain and play happily in the water, which is the good time that they spend together. At the end of the poem, they come back to the reality - toasting for their past days in a pub. With the rhetorical question at the beiginning of the poem, its climax in the middle, and a toasting at the end of it, we can see that "Auld Lang Syne" is a poem with a plot(s).

Repeatability. The wide use of refrain and chorus is one of the folk songs' features. The folk songs originate among illiterate or only partly literate people, and are often sung while dancing. By repeated chanting, the theme and lyrical atmosphere of the folk songs can be intensified greatly, achieving a lingering effect.

Burns absorbs the tradition of refrain and chorus from the old song directly. In this poem, "Sin' auld lang syne" and "for auld lang syne" are repeated several times, which remind people of their friends long long ago and time spent with their friends in the past.

Musicality. Except for the repeated orderly lines in each stanza, musicality is another feature of "Auld Lang Syne”, especially the end rhyme in the poem. End rhyme occurs at the end of a verse-line, a traditional method of organizing stanzas and poems.

Burns is so rich in musicianship that he makes "Auld Lang Syne" catchy by adopting the 
10-same-end-rhyme scheme "ain", that is, the same end rhyme for the second and fourth lines of the five stanzas of the poem, sharing the same sound "ain". It is a kind of music that sounds pretty, but it is used meaningful, too. The 10-same-end-rhyme scheme "ain” not only organizes the five stanzas and the poem but also unite the poet Burns to his friend, to readers or audience, even unite all human beings to friendship.

JIANG Jia-jun (1985) thinks that the folk songs of Burns' are not only poems, but the "literature of music", which makes Burns praised as a writer of songs by some international experts and scholars (p. 85). The feature of musicality is an important factor of the poem's popularity.

Simplicity. Another remarkable characteristic of folk songs is the using of simple words and sentences. Burns rewrites it following this tradition, he uses many simple and quite often used words in "Auld Lang Syne", such as "be, bring, run, forget, mind, foot, morning, sun, sea, and hand". Most of the sentences in the poem are also simple, which are written for the common readers and are easy for all Scots to follow and sing. Thus, it contributs to its popularity.

To sum up, the using of these artistic techniques in“Auld Lang Syne” is meaningful because it makes the poem meet the Scottish artistic taste, which sets the reader thinking, activates the reader's soul. And that is the reason why it has been passed down from generation to generation.

\section{Conclusion}

Based on Hans Robert Jauss' reception aesthetic and its key concepts of the horizon of expectations, the popularity of "Auld Lang Syne” has been explained from its production. The conclusion is that Burns' "Auld Lang Syne" owes its popularity or wide acceptance to the poet's intention, its theme, and its language features which fulfill not only Burns' expectations but also the readers' or audience's expectations.

As for Burns' intention, his personal experiences and the social condition are examined, which coincide with those of Scots. As for the theme of the poem, it is a universal truth for human beings of any time and from different cultures. In the part of the language features, the language features of "Auld Lang Syne" are discussed, such as theatricality, repeatability, musicality, and simplicity.

This is a try-out explanation for the popularity of "Auld Lang Syne" from its production, and further researches concerning its popularity are expected.

\section{References}

Burns, R. (1981). Burns’ poems (K. J. YUAN, Trans.). Shanghai: Shanghai Translation Publishing House.

Chambers, R. (1852). The life and works of Robert Burns (In 4Volumes) (Vol. II). New York: Harper \& Brothers, Publishers.

CHEN, Y. J. (2008). Fusion of time with emotion: Comments on Burns’ Auld Lang Syne. Journal of Longyan College, (4), 37-40.

Drabble, M. (2005). The Oxford companion to English literature. Beijing: Foreign Language Teaching and Research Press and Oxford University Press.

GAO, W. (2011). Emotions in Robert Burns’ Poem. Literature of Time, (2), 139-141.

Iser, W. (1974). The implied reader. Baltimore: Johns Hopkins University Press.

Jauss, H. R. (1967). Literary history as a challenge to literary theory. Baltimore: Johns Hopkins University Press.

Jauss, H. R. (1982). Towards an aesthetic of reception. Mankato: University of Minnesota Press.

Jauss, H. R., Horab, R. C., \& Zhou, N. (Trans.). (1987). Aesthetic of reception and theory of reception. Shenyang: Liaoning People's Publishing House.

JIANG, J. J. (1985). A tentative interpreting of Robert Burns’ Songs. Journal of Southwest Normal University, (3), 85-91.

Kirszner, L. G., \& Mandell, S. R. (2006). Literature: Reading, reacting, writing. Beingjing: Peking University Press. 
QIAN, Y., \& LI, S. X. (2011). Aesthetic empathy in Alud Lang Syne, a Scottish poem. Journal of the Author, (1), 85-86.

Seldem, R. (2004). A reader's guide to contemporary literary theory. Beijing: Foreign Language Teaching and Research Press and Pearson Education.

SUN, F. (2009). On the artistic features of Auld Lang Syne. Journal of Xinxiang College, (4), 105-106.

XU, B. J., \& LIU, Q. (2010). On the audience's acceptance analysized from aesthetic of reception. News World, (8), 190-191.

ZHANG, D. Q., \& WU, G. (2002). A new concise history of English literature. Shanghai: Shanghai Foreign Language Education Press.

ZHAO, D., \& MIAO, J. (2010). On the universal fraternity in Burns’ poems. News Writing Amateur, (10), 155-157.

ZHU, G. (1998). On Iser’s “Invisible Reader”. Contemporary Foreign Literature, (3), 152-157. 